from Ceylon; specimens of figure or picture writings on palm leaves from the Nicobar Islands. Some of these hints may be found useful by English travellers and others willing to promote anthropological work in the Indo. Pacific regions.

Mr. J. T. LAST contributes a paper of unusual interest to the September number of the Proceedings of the Rogal Grographical Society; he describes a visit to the little known Masai country, the region through which Mr. Icseph Thomson had to pass. $\mathrm{Mr}$. Thomsen himself sends a long letter giving an account of the first part of his journey and his forced return to the coast. He was to set out again on July 8, viâa the north side of Kili. manjaro for Mosera, far on the way to the south shore of Victoria Nyanza. Meantime it is announced that Dr. Fischer, the Germian explorer who preceded $\mathrm{Mr}$. Thomson on the same route and excited the hostility of the people, has returned to the coast. It seems impossible that he can have reached his pro. posed goal, and probably, like Mr. Thomson, has been compelled to turn back.

ON August 28 the gunboat $U_{r} d$ arrived at Tromsö with the members of the Swedish Circumpolar Expedition on board, who have wintered at Spitzbergen. I uring the Urd's voyage to the island she eicountered a fog off Beeren Island, which continued to Spitzbergen, but only a small quantity of ice was seen, viz. at South Cape. The vessel arrived at Cape Thordsten on August Io. The observations were continued until 12 midnight on A ugust 23 , in order to have a full year's magnetical observations. On the 24 th the houses were cleared, the windows nailed up, and the coors locked, and on the 25th the Urd steamed out of the Icefjord. In Green Harbour the post was taken on board from the Norwegian hunters, and steering west of the Beeren Island the coast of Norway was sighted on the 28 th. No ice wa. encountered. The ship is expected in Gothenburg on the 6:h inst.

WE are glad to learn that both the Dutch International Polar Expedition and the Danish Expedition under Lieut. Hovgaard are safe. A Reuter's teleyram from Vardoe says :-The steamer $O b i$, belonging to $M$. Sibiriakoff, has arrived here. The captain picked up on the 25th ult., near Waigatz, the members of the Dutch Yolar Expedition steamer Varna, which foundered on July 24 in lat. 71 , long. 63 . The captain further states that the Danish exploring vessel Dijmphna had been ice-bound in that region throughout the winter. All was, however, well on board, and the captain of the Dijmphna felt confident of getting into open water. The crew of the Varna, which left the Dijmphno on the Ist ult., will be brought to HIammerfest by the steamer Noraenskjold. 'The Varna had on board the Dutch section of the International Polar Expedition. She left Amsterdam on July 5,1882 , bound for Dickson's Harbour, at the mouth of the Yenisei. The Danish Polar steamer Dijmphna, under command of Lieut. Hovgaard, left Copenhagen on july I8, 1882, al:0 bound for the Arctic Seas, and the Nordenskjold, Swedish exploring steamer, left Tromsö about July 3,1882 , bound for Novaya Zemlya. The Louise is a trading steamer which left Bremen of June 27 last, and Hammerfest on July 17 , bound for the Yenesei.

\section{ELECTRICAL UNITS}

THE following is the Report (omitting the appendix) to the Lords of the Committee of Council on Education by the Commit tee of Advice ${ }^{1}$ with respect to the International Congress for the Determination of Electrical Units to be held at Paris in October, 1883.

The first International Electrical Exhibition was held in Paris during the months of August, September, and October, I88I, under the auspices of the French Government, who supplemented it by calling together a Congress of the leading scientific and practical electricians of all countries England was represented by the following official delegates :-

The Ambassador to France, Sir F. Abel, C.B., F.R.S., Prof. W. G. Aciams, F.R.S., Lieut. R. W. Anstruther, R.E., Prof. W. E. Ayrton, F.K.S., Prof. W. F. Barrett, Sir Charles Bright, M.I.C.E., Commissioner at the International Electrical Exhibition, Paris, Prof. Chrystal, F.R.S., Mr. Latimer Clark, M.I.C.E., Prof. R. B. Clifton, F.R.S., the Earl of Crawford

I The President of the Royal Society, the late Mr. W. Spottiswoode, was a member of the Committee, but his illness and death prevented his taking part in its proceed.ngs. and Balcarres, F.R.S., Commissioner-General at the Inter national Electrical Exhibition, Paris, Mr. W. Crookes, F.R.S. Mr. Warren de la Rue, D.C.L., F.R.S., Prof. T. Dewar, F.R.S., Prof. J. D. Everett, F.R.S., Prof. G. Fitzgerald, F.R.S., Prof. G. Carey Foster, F.R.S., Dr. J. H. Gladstone, F.R.S., Mr. J. E. H. Gordon, Mr. E. Graves, Engineer-inChief, Po:tal Telegraphs, Dr. J. Hopkinson, F.R.S., Prof. Hughes, F.R.S., Commissioner at the International Electrical Exhibition, Paris, Prof. Fleeming Jenkin, F.R.S., Mr. J. F. Moulton, F.R.S., Mr. W. H. Preece, F.R.S., Lord Rayleigh, F.R.S., Sir W. Siemens, D.C.L., LL.D., F.R.S., Prof, H. Smıth, F.R.S., Mr. Willoughby Snith, Mr. C. E. Spagnoletti, Mr. W. Spottiswoode, D.C.L., LL.D., P.R.S., Mr. A. Stroh, Prof, P. G. Tait, F.R.S.E., Sir William Thomson, LL.D., F.R.S., Prof. J. Tyndall, D.C.L., LL.D., F.R.S., Mr. Cromwell Varley, F.R.S., Mr. C. V. Walker, Lieut.-Col. Webber, R.E., Commissioner at the International Electrical Exhibition, Paris.

Many very important electrical questions were fully discussed, and a universal and international system of units for expressing the results of electrical measurements and observations vas determined upon. All parts of the globe being now connected together by a great network of telegraphy, constructed and maintained by every civilised nation, it has becoine a matter of great conimercial as well as scientific importance that uniformity should be introduced in modes of working, measuring, anc observing throughout the world. The Paris Congress of $188 \mathrm{r}$ has laid the foundation of such a desirable result.

The Congress of I88I referred certain questions to a second Conference, held in the month of October, 1882.

This second Conference was divided into three Sections (i.e. Commissions); the first dealing with "Electrical Units"; the second with "Earth Currents and Lightning l'rotectors"; and the third with the question of "A Standard of Light."

Lord Rayleigh, Sir William Thomson, Prof. Carey Foster, Prof. Fleeming Jenkin, and Lr. Hopkinson were nominated as delegates from England, but Sir Willian Thomson was the only one present, and he devoted his time principally to the first question.

First Commission. - The Electrical Congress of I88I adopted, as the fundamental system of units for scientific purposes, a system founded upon the employment of the Centimetre, the Gramme, and the Second as units of length, mass, and time re-pectively, and hence known as the C.G.S. system of units. The Congress also defized, and adopted a nomenclature for, a system of electrical standards of such magnitudes as to be as far as possible generally convenient $f$.r practical use, each practical standard being a decimal multiple or submultiple of the corresponding C.G.S. unit. ${ }^{1}$ Of these standards, those to which reference is most frequently required are the following, namely :- -

The Ohm, defined as one thousand million C.G.S. units of electric resistance.

The Volt, defined as one hundred million C.G.S. units of electromotive force.

The Ampere, defined as one-tenth of a C.G.S. unit of electric current, being the current maintained by an electromotive force of one volt in a conductor of resistance one ohm.

It was further agreed by the Congress that, with a view especially to facility of reproduction, the resistance denoted by the ohm should be stated as being the resistance of a column of mercury at the temperature of melting ice, of one square millimetre in cross-section, and of a length to be ascertained by experiment.

Accordingly the principal question referred to the first section of the Conference of 1882 was the determination of the length of a column of mercury, of the above-mentioned cross-section and temperature, which had an electrical resistance of one thousand million C.G.S. units. In reference to this question the Conference adopted the following resolutions, namely:-

First Resolution. - "The Conference considers that the determinations hitherto made do not present the necessary degree of concordance for fixing the numerical value of the ohm in terms of a column of mercury.

I It is satisfactory to your Committee to be able to say that the C.G S. system of units was widely used among English physicists before its adoption by the Electrical Congress in $188 \mathrm{r}$, it having been recommended by a Con by the Electrical Congress in 1881, it having been recommended by Committee of the British Associaticn in 1875 ; and also that the svstem practical standaris adopted by the Congress is nearly identical with that previcusly in use in England and first suggested in a paper by Mr I atime Clark and Sr Charles Fright read befure the British Asscciation in Manchester in $\mathbf{r} 86 \mathrm{r}$. 
"It is therefore of opinion that it is necessary to continue investigations in relation to this question."

Second Resolution.- "The Conference expresses the wish that the French Government should take the necessary measures for placing one or several standard resistances at the disposal of those men of science who are devoting themselves to the investigation of absolute units, in order to facilitate the comparison of results."

Third Resolution.- "The Conference is of opinion that so soon as the results of the various investigations shall be so far accordant that it is possible to guarantee an accuracy of one part in a thousand, it will be proper to accept this degree of approximation for the purpose of fixing the value of the practical : tandard of resistance."

Fourth Resolution.- "The Conference expresses the wish that the French Government may be pleased to communicate to the Governments represented at the Conference a desire to the effect that each of them, in view of the importance and urgency of arriving at a practical solution, should take the necessary steps to encourage investigations, on the part of its own nation, in relation to the determination of the electrical units."

Upon these resolutions your Committee have to observe that experiments made in the Cavendish laboratory of the University of Cambridge by Lord Rayleigh and other experimenters working in conjunction with him, confirmed by independent experiments by different methods also made in the Cavendish laboratory, appear to have attained a greater degree of accuracy than that agreed upon by the Conference as sufficient for present requirements.

Your Committee are therefore of opinion that, so far as the determination of the standard of electrical resistance is concerned, it is unnecessary to advise the Government to take any steps in the matter until fur:her researches raise fre-h questions relating thereto, as the results obtained at Cambridge seem to possess all the accuracy obtainable at present.

In the Second Commission, which dealt with earth current and lightning protectors, various resolutions were carried, which it will be convenient to deal with separately.

The first resolution proposed that the different Governments should organise regular observations upon the behaviour of atmospheric electricity. In reference to this your Committee understand that regular and continuous observations have been made for some years at Greenwich and at Kew, and without further and more detailed recommendations on the part of the Congress as to the special observations they propose, your Committee are not in a position to recommend any further steps to be taken by the Government.

The second resolution expressed the wish that a detailed study should be made of the effects of thunderstorms upon telegraphic lines and telephotic lines, and upon buildings connected with wires.

In regard to this your Committee have nothing to advise until the Commission have formulated their requirements in more detail ; when this has been done, it is under tood from the delegates of the Post Office that the fullest consideration will be given to the matter, with a view to afford every assistance in the power of that department.

The third resolution dealt with the question of the observation of earth currents. Your Committee would observe that continuous records are made by photography at Greenwich of all earth currents occurring upon two telegraphic lines proceeding from the Observatory nearly at right angles to each other; and careful returns are collected from all the principal Post Offices in the United Kingdom of every unusual and disturbing magnetic storm; and they recommend that a description of the methods employed in this country, which, with notes bearing on the subject, is appended, be submitted to the Congress, with the view to their universal adoption, if approved, in order that similar observations may be carried out throughout the world. Your Committee at the same time are of opinion that, with a view to meet the wishes of the Congress, some effort might be made to secure observations on Sundays on those telegraphic lines where the staff is necessarily present, but where the number of messages sent is very small.

The fourth resolntion suggests the establishment of an international network of telegraph wires for the purpose of automatically registering at a central station meteurological changes.

In view of the great expense that would be incurred in establishing a system of wires for automatically recording telemeteorographical obiervations, your Committee concur with the

Congress in considering the time has not arrived for adopting that proposal.

The fifth resolution expresses the view that lightning protectors and conductors should everywhere be submitted to a periodical inspection.

This recommendation is at present carried out by the War Office in connection with the buildings under its charge, and the subject has been considered by a Committee of Delegates from the Society of Telegraph Engineers, the Physical and Meteoro logical Societies, and the Institute of British Architects. There is not in England any authority legally competent to discharge the duty as far as the general public is concerned, and it is therefore impossible in England to carry out this proposal in its entirety; but the Committee concur in the advisability of adopting that course where it is found possible to do so.

The sixth resolution implies that the returns of storms and their effects upon buildings and telegraphic lines should be subject to statistical examination.

Your Committee consider that the observations necessary for ascertaining the effects of lightning other than on telegraph wires cannot be carried out by the Government, owing to the non-existence of a competent staff throughout the Kingdom and that such observations must of necessity be left to private observers. Your Committee recommend, however, that the Meteorological Office be supplied with forms of questions such as may be finally adopted by the Congress for distribution to meteorological observers throughout the United Kingdom. The information desired by the Congress would, it is hoped, thus be obtained.

With reference to the effect of lightning on telegraph lines, the delegates of the Post Office who attended the meeting of the Committee stated that their department would be able to adopt any form of questions, on which returns could be made, finally proposed by the Congress.

Your Committee recommend that the Government should procure such adoption by the Post Office in the United Kingdom, and should also use its influence to cause the same form to be adopted by the Indian and Colonial Administrations and by the various submarine and other telegraphic and telephonic companies at home and abroad.

THIRD Commission. - This Commission dealt with the establishment of a standard of lisht by reference to which various electric and other lights could be measured. At the present moment there are two in existence : the one is the French Carcel Lamp, and the other is the English Standard Candle, the former being nearly ten times the latter. No better standard was proproposed at the Conference. This question remains in abeyance for further investigation.

Your Committee fully recognise the importance of the recommendation to adopt a uniform standard of light.

A Committee appointed by the British Association are now considering the question, and pending their Report your Committee have at present no recommendations to make.

It will be seen from this Report that there are matters of high scientific and practical importance which will be brought before the approaching Congress, and your Committee are of opinion that England should be represented, to bring the views above expressed before it, and to assist at its deliberation:. The value of the decisions at which the Congress may arrive depends mainly on its international character, and the non-representation of this country would be a serious blow to the authority of its utterance; and perhaps cause the same confusion in electrical science which now exists in others where international accord has not been established.

(Signed) 